\title{
TIMSINA ISTVÁN
}

\section{Az önkéntes eredményelhárítás érvényesülése egy életellenes büncselekmény elkövetésekor}

\begin{abstract}
A büntető törvénykönyvről szóló 2012. évi C. törvény 10 . § (4) bekezdés b) pontja szerint nem büntethető kísérlet miatt, aki az eredmény bekövetkezését önként elhárítja. A kísérlet lehet befejezett vagy befejezetlen. A befejezetlen kísérlet esetében a büntetlenség két feltételhez kötött: egyrészröl el kell maradnia a büncselekmény befejezésének, másrészről ennek az elmaradásnak az elkövető önkéntes elállására kell visszavezethetőnek lennie. Befejezett kísérlet esetében nem önkéntes elállás, hanem az eredmény bekövetkezésének önkéntes elhárítása garantál büntetlenséget. Elhárításnak csak aktív magatartás minősülhet, amely megszakítja az eredmény bekövetkezéséhez vezető okfolyamatot. Az elhárító cselekmény indoka éppen úgy közömbös, mint az elállásé a befejezetlen kísérlet esetében; itt is az önkéntesség a feltétele a büntetlenségnek. ${ }^{1}$

Az előbbiek alapján a halál mint eredmény bekövetkezéséhez vezető folyamat történéseinek releváns mozzanatait és a köztük megjelenő ok-okozati kapcsolatot célszerü górcső alá venni. Az okfolyamat mint minden eseménysor térben és időben keletkezik - ami a külvilág számára is észlelhető, azaz rögzíthető és rekonstruálható -, „,mozgási energiáját” a cselekvő ember tudata által vezérelt szándék indítja el.

Az okozati összefüggés keretében csak arra a kérdésre kell választ adni, hogy egy adott magatartás és egy meghatározott eredmény között áll-e fenn olyan objektív jellegü kapcsolat, amely a magatartásnak az eredmény bekövetkezésében játszott szerepét bizonyítja. Ha tehát valakinek a magatartása gondolatban nem hagyható el anélkül, hogy az eredményen változás ne állna be, az a magatartás az eredménnyel okozati összefüggésben van. ${ }^{2}$
\end{abstract}

1 Földvári József: Magyar Büntetőjog. Általános rész. Osiris Kiadó, Budapest, 2002 2 Uo. 


\section{Az önkéntes eredményelhárítás objektív feltétele}

Az önkéntes eredményelhárítás érvényesülését valóságos élethelyzetekből kifejlődő bírói joggyakorlat vázolásával kísérlem meg bemutatni. Egy esetben az irányadó tényállás szerint az igen ittas állapotú, kitartóan tolakodó, garázda, agresszív magatartást tanúsító, majd tettlegességet kezdeményező terhelt $95 \mathrm{~mm}$ pengehosszúságú, élesre köszörült késsel a sértett arca-nyaka irányába szúrt. Ez után újabb szúrást adott le ugyancsak a sértett nyakára. A sértett elhárító mozdulata ellenére a felülről lefelé irányuló kis-közepes erejü, hat és három centiméter mélységü szúrások a sértett nyakát a közös fejverőértől és nyaki gyüjtőértől néhány milliméterre érték, ennek következtében nyolc napon túl, illetve nyolc napon belül gyógyuló sebzések keletkeztek. A megismételt szúrásokkal okozott sérülések életfontosságú érképleteket takaró testtájékra irányuló célzott mozdulat nyomán jöttek létre. A szúrások közvetlen közelében lévő nyaki gyüjtőér és közös fejverőér sérülése - köztudottan - életveszélyes vagy akár halálos következménnyel is járhatott volna. A sértett által elszenvedett sérülések azonban életveszélyesek nem voltak, így nem indítottak el halálos eredményhez vezető folyamatot.

Az önkéntes eredményelhárítás alapvető feltétele, hogy az elkövető olyan helyzetben legyen, hogy módja legyen a halálhoz vezető okfolyamat megszakítására, lehetősége legyen az eredmény elhárítására. ${ }^{3}$

A bírói gyakorlat egy másik esetben is megerösítette az említett körülmény fennállásának szükségességét, amikor is az irányadó tényállás szerint a terhelt a sértett támadó fellépését feltételezve lőfegyvert vett magához, amelyet betárazás után csőre töltött. A kezében tartott fegyverrel azt akarta elérni, hogy a sértett menjen haza. A sértett erre akként reagált, hogy ruhátlan mellkasát mutatva azt kiabálta: Gyere és lőj! A pisztoly csövének kimeneti nyílása és a sértett közötti távolság legfeljebb $192 \mathrm{~cm}$ lehetett, amikor a terhelt a sértett bal mellkasfelére célzottan egy lövést adott le. A lövedék a bal kulcscsont harmada felett hatolt a sértett testébe és a szegycsont felett, a jobb oldali kulcscsont harmada magasságában rekedt meg úgy, hogy a mellüreg nem nyílt meg.

Az önkéntes eredményelhárítás mint büntethetőséget megszüntető ok alkalmazhatóságának pedig az az akadálya, hogy a lövés folytán - mivel a lövedék a kulcscsont magasságában úgy akadt el, hogy a mellüreget nem nyitotta meg - a halálhoz vezető okfolyamat nem indult meg. Ebből következően

$3 \mathrm{EBH}, 2008 / 1756$. 
- életveszélyes állapot hiányában - a terhelt nem került abba a helyzetbe, hogy az eredményt elhárítsa. ${ }^{4}$

\section{Az eredményt elhárító cselekmény}

A bírói gyakorlat egységes álláspontját tükrözi az az eseti döntés, amikor az irányadó tényállás szerint a terheltben ölési szándék alakult ki, amire az elkövetés eszközeként használt kés méretéből, a támadott testtájékból, valamint a vádlott által a cselekmény megkezdésekor tett kijelentésből lehetett okszerü következtetést vonni. Amikor a vádlott észlelte, hogy a sértett nagyon vérzik, elszaladt, és a közeli nyilvános telefonfülkéböl értesítette a mentőket, arra is megkérve öket, hogy szóljanak a rendöröknek. Ez után visszament a helyszínre, és a mentő telefonon adott utasítása szerint kötést tett a sértett nyakára. A kiérkező mentőt és rendőröket a helyszínen várta meg.

Mivel a vádlott az ölési cselekményt követően mindent megtett a sértett életének megmentésért, ami eredményre vezetett, ezért magatartása önkéntes eredményelhárításnak tekintendő. Ha ugyanis a mentőktől nem kér segítséget telefonon, illetve a sértett nyakára nem tett volna kötést, akkor a sértett nem marad életben. A terhelt elkövetés után tanúsított magatartása tehát azt mutatja, hogy a szándéka irányt váltott, ekkor már a sértett életben maradását kívánta.

A vádlott magatartása tehát meghatározó és nélkülözhetetlen volt a sértett életben maradása tekintetében, mert az ölési cselekménnyel elindított okfolyamatot - amely egyébként szükségszerủen a sértett halálához vezetett volna - döntő mértékben az időközben megváltozott szándéka és nem a véletlen szakította meg. ${ }^{5}$

Egységes az igazságszolgáltató hatalmi ág joggyakorlata a tekintetben is, hogy a közremüködő bevonásával megvalósuló eredményelhárítás is kiváltja a büntethetőség megszünését, amit a következő eset is igazol. Az ítéleti tényállás szerint a sértett és a terhelt az utcán dulakodott, majd a vádlott a házába bemenve egy nyolc centiméter pengehosszúságú rugós kést vett magához. Késsel a kezében visszament az utcára, ahol a sértett megindult a vádlott irányába. Amikor odaért hozzá, a terhelt a jobb kezében tartott rugós késsel egy alkalommal, közepes-nagy erővel, fentről lefelé irányuló mozdulattal a vele

$4 \mathrm{BH}, 2010 / 57$

$5 \mathrm{BH}, 2008 / 79$. 
szemben lévő sértett mellkasába szúrt. A kés az V. bordaközben hatolt be a sértett testébe, ahol egy két centiméteres szúrt metszett jellegü sérülés keletkezett. A szúrcsatorna a VI. bordaköz irányába haladt, öt centiméter hosszú volt, a mellüregbe hatolt, a szív környéki zsírszövetig. A mellüreg megnyílása közvetett életveszélyes állapotot idézett elö.

A szúrás után a sértett eltávolodott a helyszíntől, a vádlott pedig bement a házba, és szólt az élettárásnak és egy másik jelenlévőnek, hogy hívják a mentőt és a rendőrséget. A kiérkező mentők a sértettet kórházba szállították, ott megmütötték; a szakszerủ orvosi ellátás hiányában a sértett meghalt volna.

Az emberölés büntettének kísérlete esetén egyenértékủ a vádlott részéröl az önkéntes eredményelhárítás, ha azt akár maga, akár más személy közremüködésének felhasználásával teszi. ${ }^{6}$

Az önkéntes eredményelhárító cselekmény kifejtöjével szemben a következő jogeset kapcsán született döntés további feltételt határozott meg. A tényállás szerint a terhelt már előzőleg is kijelentette, hogy a sértettet „kinyírja”, „megdögleszti”, „tök mindegy, hogy öllek meg”. Cellatársai elött kijelentette, hogy „fel kellene akasztani a sértettet, hátha amnesztiát kapnának”. „Az öngyilkosság látszatát kellene kelteni, írassanak előtte vele búcsúlevelet.” A terhelt által készített eszköz az általa használt módon alkalmas volt az élet kioltására. Közismert, hogy az akasztáskor a nyakon keletkezett szorító-nyomó erőbehatás következményeként a halál azonnal bekövetkezhet. Az ágyról lelökött sértett nyakán a hurok megfeszült, lábai ötven centiméterre voltak a földtől, és néhány másodpercig ebben a helyzetben lógott a levegőben. Ennek következtében a nyakon akasztásos zúzódást szenvedett, rövid ideig öntudatlan állapotban volt. Az igazságügyi orvos szakértő szerint a nyak elülső felszínét ért szorító-nyomó erőbehatás a hirtelen beálló szív- és légzésbénulás folytán halálhoz is vezethetett volna. A terhelt, amikor a sértettet a nyakába tett megszorított hurokkal az emeletes ágyról lelökte, a halálos eredmény bekövetkezése lehetőségét elöre látta, és a következményekbe belenyugodva cselekedett. Mivel az eredmény nem következett be, a terhelt cselekménye kísérleti szakban megrekedt. Jelen esetben a sértett ágyról lelökésével az ölési kísérlet befejezetté vált. A terhelt e cselekménnyel a maga részéről mindent megtett annak érdekében, hogy a halálos eredmény bekövetkezzék. Ezzel indította el ugyanis azt az okfolyamatot, amely az ő további magatartása nélkül is alkalmas volt arra, hogy a cselekmény befejezetté váljék. A terhelt javára az önkéntes eredményelhárítás nem alkalmazható, mivel az olyan aktív és si-

$6 \mathrm{BH}, 2005 / 271$. 
keres magatartást kíván az elkövetőtől, amely nem külső körülmények hatására, hanem döntően a terhelt belső indíttatásából, önálló akaratelhatározásából fakad.

A bírói gyakorlat nem kívánja meg, hogy az elkövető az eredményt egyedül és kizárólag maga hárítsa el, ezt az általa hívott más személy közreműködésével is megteheti. Szükséges azonban, hogy az elkövető tevőleges magatartása indítsa el azt az okfolyamatot, ami végül az eredmény elmaradásához vezet. Az imént említett esetben a vádlott kezdeményezőleg semmit nem tett. A sértett életének megmentése érdekében más személyt sem vett igénybe, a zárkatársak segítségét nem kérte. Az eredmény elmaradásához vezető okfolyamatot az egyik zárkatársnak a terhelttől független fellépése indította el. A biztosan bekövetkező halált a zárkatárs azon tevékenysége hárította el, hogy az emeletes ágyra felugorva elvágta a sértett nyakán a kötelet, ennek során kapcsolódott be végül a terhelt, aki a sértett testének megemelésében segédkezett. A vádlottnak ez a magatartása azonban önkéntes eredményelhárításként nem értékelhető. ${ }^{7}$

\section{A konkrét esetben érvényesülő önkéntes eredményelhárítás}

Az irányadó tényállás szerint a terhelt a testvérével és az édesanyjával él együtt az egyik nyugat-magyarországi település társasházi lakásában. A gyanúsított és a testvére rendszeresen fogyasztanak alkoholt, és ittas állapotban gyakran összevesznek. Ez történt az inkriminált cselekmény bekövetkezésének napján is. A sértett és a gyanúsított a szobában az ágyon ültek egymás mellett, a gyanúsított vacsorázni akart, kezében egy tizenkilenc centi hosszú és nyolc centi pengehosszúságú svájci bicskát tartott, az ölében az ételt tartalmazó tálca feküdt, miközben veszekedtek. Ennek során a gyanúsított a jobb kezében lévő bicskával a sértett nyaka bal oldalába szúrt. A sértett vérzett, ezt észlelve a gyanúsított azonnal átfutott a szomszéd lakáshoz, dörömbölt, és amikor a szomszéd ajtót nyitott, kérte, azonnal hívjon mentőt, mert megszúrta a testvérét, gyorsan intézkedjen, Kérésének eleget tett a szomszéd, így a mentők rövidesen kórházba szállították a sértettet.

A gyanúsított cselekménye következtében a 46 éves sértett nyaka bal oldalának szúrt-metszett jellegű sérülését szenvedte el. A sérülés csekély, kis

7 BH, 2005/2. 
erejü él- és hegyhatásra keletkezett, kialakulhatott késsel történő szúrás következményeként, a tényleges gyógytartam nyolc napon belüli.

Mindamellett az elkövetés módját, jellegét, a sérülés anatómiai helyét, a használt eszközt figyelembe véve, reálisan fennállt az elszenvedettnél súlyosabb, nyolc napon túl gyógyuló sérülés lehetősége. Nyaki nagy erek, verövagy visszér átmetszése, sértése révén életveszély reális lehetősége felvetődik.

Az említett tényállásban az életveszély mint eredmény reális lehetőségének felvetődésével az eredményhez vezető okfolyamat megindult, tehát a terhelt objektíve olyan helyzetbe került, hogy az eredményt elháríthassa.

Azzal, hogy a gyanúsított minden külső körülménytöl függetlenül, belső indíttatásból a saját akaratelhatározása alapján lépett fel kezdeményezően, érzékelhető a szándéka az irányú változása, hogy - a szomszédoktól történő segítségkéréssel - megakadályozza az életveszélyes állapot kialakulását.

\section{Összegzés}

Befejezett kísérlet esetén az eredmény bekövetkeztéhez vezető eseménysort a terhelt már csak akkor tudja az önkéntes eredményelhárítás mint büntethetőséget megszüntető ok alkalmazhatósága szempontjából értékelhető módon megszakítani, ha az eredményhez vezető okfolyamat ténylegesen megindult, és azt saját belső indíttatásából maga vagy az általa hívott közremüködő szakítja meg.

Jól látható tehát, hogy az élet elleni büncselekmények nyomozásakor fokozott figyelmet kell fordítani minden olyan körülményre, amely releváns lehet a terhelt büntetöjogi felelősségének megállapíthatósága szempontjából. Kiemelve, hogy az ilyen jellegü ügyekben a szemlének döntő jelentősége van, továbbá - a tényállás tisztázása érdekében - az észlelő személyek vallomásának felvétele nem tür halasztást. 